\title{
Assessment of Reliability in Isokinetic Testing Among Adolescent Basketball Players
}

\author{
Humberto M. Carvalho' ${ }^{1}$, Manuel J. Coelho E Silva', Enio Ricardo Vaz Ronque ${ }^{2}$, \\ Rui S. Gonçalves ${ }^{3}$, Renaat M. Philippaerts ${ }^{4}$, Robert M. Malina ${ }^{5,6}$ \\ ${ }^{1}$ Faculty of Sport Science and Physical Education, University of Coimbra, Portugal, \\ ${ }^{2}$ Department of Physical Education, Universidade Estadual de Londrina, Brazil, ${ }^{3}$ College of Health Technology, \\ Polytechnic Institute of Coimbra, Portugal, ${ }^{4}$ Faculty of Medicine and Health Sciences, Department of Movement and \\ Sports Sciences, Ghent University, Belgium, ${ }^{5}$ Department of Kinesiology, University of Texas at Austin, Texas, USA, \\ ${ }^{6}$ Department of Health and Physical Education, Tarleton State University, Stephenville, Texas, USA
}

Key words: maturation; strength; young athletes; anthropometry.

Summary. Background. The reproducibility of day-to-day testing of isokinetic concentric and eccentric muscular actions among adolescent basketball players aged 14 to 16 years and relationships of mean within-subject variation in two isokinetic testing sessions with chronological age, biological maturation (estimated age at peak height velocity), training experience, body size, lower-body morphology, and initial strength performance were evaluated.

Material and Methods. The sample included 27 basketball players who completed replicate test sessions of 5 repetitions of reciprocal concentric and eccentric knee extensions and flexions at $60^{\circ} \mathrm{s}^{-1}$. A randomly selected subsample of 8 players completed a third testing session to confirm reliability estimates.

Results. Coefficients of variation (CV) between sessions 1 and 2 ranged from $8.1 \%$ to $17.4 \%$, and intraclass coefficients (ICCs) ranged from 0.72 to 0.89. For sessions 1 and 3, CVs ranged from $3.9 \%$ to $6.0 \%$, and ICCs ranged from 0.95 to 0.99 . The initial level of strength of eccentric knee flexion $(r=-0.43)$ and eccentric knee extension $(r=-0.42)$ were correlated $(P<0.05)$ with eccentric knee extension within-variation between two sessions. Training experience $(r=-0.37, P<0.05)$ and initial values of concentric knee flexion $(r=-0.62, P<0.01)$ were correlated with concentric knee flexion within-subject differences. Within-subject variation of eccentric knee extension was correlated $(P<0.05)$ with chronologic age $(r=0.41)$, estimated age at peak height velocity $(r=-0.38)$, body size ( $r=0.41$ to 0.47$)$, and leg volume $(r=0.39)$.

Conclusions. Familiarization sessions may improve the reliability of concentric and eccentric knee isokinetic strength testing at $60^{\circ} \mathrm{s}^{-1}$ in adolescent basketball players. Age, maturity status, and training experience of young athletes should be considered when testing knee isokinetic strength at $60^{\circ} \mathrm{s}^{-1}$.

\section{Introduction}

Isokinetic dynamometry is generally considered the best protocol of dynamic strength measurements (1). However, the literature suggests inconsistency in the application of isokinetic measurement protocols, which may hinder data interpretation (2). Valid isokinetic data require reliable assessment techniques for the peak moment of force, mean peak moment of force, and angle at peak moment of force. It is suggested that coefficients of variation (CV) should not be greater than $\pm 6.1 \%$, and intraclass correlations (ICC) should be greater than 0.88 (3). Most of the available information, however, is derived from studies on adult males and females.
Minimal measurement error (reliability) of performance of a test refers to the consistency or reproducibility of performance when someone performs the test repeatedly (4). A test with poor reliability is unsuitable for tracking changes in performance between trials, and it lacks precision for the assessment of performance in a single trial (5). The magnitude of measurement error in isokinetic testing in general and in particular with young athletes has not been systematically addressed. Young athletes are a highly select group with regard to skill, performance, size, and physique; variation in maturity status is an additional factor affecting growth in size and function especially during adolescence $(6,7)$.
Correspondence to H. M. Carvalho, Faculdade de Ciências do Desporto e Educação Física, Estádio Universitário Coimbra Pavilhão-III, 3040-156 Coimbra, Portugal E-mail: hmoreiracarvalho@gmail.com
Adresas susirašinèti: H. M. Carvalho, Faculdade de Ciências do Desporto e Educação Física, Estádio Universitário Coimbra Pavilhão-III, 3040-156 Coimbra, Portugal El. paštas: hmoreiracarvalho@gmail.com 
Studies on the reproducibility of the isokinetic peak moment of force assessment in children and adolescents are limited, especially on the eccentric action mode (8). Several reports using a test-retest design with youth suggest that a familiarization session may reduce learning effects (9) and that familiarization may be more important in protocols which include eccentric actions (10). Learning effects may interfere with statistical estimates of reliability (11).

The purpose of this study was to investigate the reproducibility of day-to-day testing of isokinetic concentric and eccentric muscular actions in youth basketball players aged 14 to 16 years. Measurement error in isokinetic testing is hypothesized. Interrelationships of age, biological maturation, training experience, body size, lower-body morphology, and initial strength performance with an average within-subject variation between two test sessions of different muscular actions were also examined.

\section{Materials and Methods}

Experimental Approach to the Problem. Isokinetic dynamometry is a widely recognized component of assessment in athletes (12). As such, reliability of the protocols is important as it provides an indication of the biological and technical variation associated with assessment procedures and conditions (13).

Day-to-day variation in isokinetic assessments was based on repeated tests within a period of 3 to 5 days on the 27 basketball players with at least 48 hours between test sessions. The group of 8 randomly selected athletes from the total sample completed a third testing session to confirm the attainment of optimal performance after the first testing session. Relationships of within-subject variation between two testing sessions with chronological age, duration of formal training, body size, estimated lower-limb volume, and initial strength values (first test session) were examined using correlations.

Subjects. The sample included 27 male adolescent basketball athletes aged $14-16$ years at the time of testing, 25 of Portuguese and 2 of African ancestry. From this group, 8 athletes were tested a third time under the same conditions. Participation in the study was voluntary, and each participant's parents (or legal guardians) were provided informed consent following an explanation (in compliance with the Declaration of Helsinki) of the nature of the experiment and any possible risks associated with participation. All procedures were approved by the Scientific Committee of the Faculty of Sport Science and Physical Education of the University of Coimbra. Chronological age was recorded to the nearest 0.1 year by subtracting birth date from the date of the first laboratory assessment. The duration of formal training was documented during an interview.
Anthropometry. Anthropometry was assessed by a single experienced observer following procedures described in Lohman et al. (14). Stature and sitting height were measured with a portable stadiometer (Harpenden model 98.603, Holtain Ltd, Crosswell, United Kingdom) to the nearest $0.1 \mathrm{~cm}$. Leg (subischial) length was estimated as stature minus sitting height. Body weight was measured with a portable scale (Seca model 770, Hanover, MD, United States) to the nearest $0.1 \mathrm{~kg}$. To estimate the total leg volume of the dominant leg (15), the following parameters were recorded: circumferences at the gluteal furrow (the highest possible horizontal circumference), mid thigh (the largest possible mid thigh circumference), minimum circumference above the knee, maximum circumference around the knee (patella level), minimum circumference below the knee, maximum calf circumference and minimum ankle circumference; anterior and posterior skinfolds at the level of mid thigh circumference as well as the medial and lateral skinfolds at the level of maximum calf circumference; and lengths between each circumference from the gluteal furrow to the minimum ankle circumference (e.g., distance between mid thigh and minimum thigh circumferences), sum six partial lengths. Although the protocol is valid, it tended to overestimate total lower-limb volume (approximately 6\%) compared estimates based on dual-energy x-ray absorptiometry in 37 young athletes aged 13-22 years. Correlation between estimated volumes ranged between 0.91 and 0.96 (unpublished results).

Based on 18 participants measured twice within one week, intraobserver technical errors of measurement were $0.54 \mathrm{~cm}$ for stature, $0.74 \mathrm{~cm}$ for sitting height, $0.88 \mathrm{~kg}$ for body weights, 0.29 to $0.74 \mathrm{~cm}$ for circumferences, and 0.16 to $0.46 \mathrm{~cm}$ for lengths. The estimated errors were within the range reported for intra- and interobserver errors for a variety of studies (16).

Maturity Status. Age at peak height velocity (APHV) was estimated with the maturity offset protocol (17). The technique estimates time before or after peak height velocity (PHV) from chronological age, height, weight, sitting height, and estimated leg length (height minus sitting height) as follows:

Maturity offset $=-9.236+[0.0002708 \times$ (leg length $\times$ sitting height $)]+[-0.001663 \times($ age $\times$ leg length $)]+[0.007216 \times($ age $\times$ sitting height $)]+$ $[0.02292 \times($ body weight/stature $) \times 100]$

Negative values indicated time before PHV and positive values indicated time after PHV. Negative offset values were added to and positive offset values were subtracted from chronological age to estimate APHV. 
Isokinetic Assessment. The isokinetic assessment was completed within a week period with at least 48-hour interval between sessions. Subjects were instructed not to eat for at least 3 hours and not to drink coffee or beverages containing caffeine for at least 8 hours before each testing session. Subjects wore similar clothing and the same footwear on each testing occasion. No participant was suffering from lower extremity musculoskeletal injury at the time of testing or during 6 months before testing.

Isokinetic concentric and eccentric knee extension and flexion were measured using a calibrated dynamometer (Biodex System 3, Shirley, NY, United States) at angular velocities of $60^{\circ} \mathrm{s}^{-1}$. After the anthropometric assessment, the subject performed a 10-minute cycling warm-up on a Monark cycle ergometer (Monark 814E, Varberg, Sweden) with minimal resistance (basket supported) at $60 \mathrm{rev}$ $\mathrm{min}^{-1}$ and 2-minute static stretching of the hamstring and quadriceps muscles. Athletes were then placed in a seated position, adjusted according to the manufacturer guidelines in a standardized $85^{\circ}$ hip flexion from the anatomical position. The lever arm of the dynamometer was aligned with the lateral epicondyle of the knee, and the force pad was placed approximately 3 to $5 \mathrm{~cm}$ superior to the medial malleolus with the ankle in a plantigrade position. Range of motion during testing was set using voluntary maximal full extension $\left(0^{\circ}\right)$ to $90^{\circ}$ of knee flexion. Cushioning was set using a hard deceleration (according to manufacturer guidelines) and, therefore, $90^{\circ}$ constituted the range of motion tested. At the beginning of each session, the participant was asked to relax his leg so that passive determination of the effects of gravity on the limb and lever arm could be accounted for. The participant was instructed to grasp firmly the handgrips at the sides of Biodex System 3 seat during the test procedure. In the concentric action, the participant was instructed to push the lever arm during extension and pull during flexion as hard and fast as possible; in the eccentric action, the subject was instructed to resist the lever arm during extension and flexion as hard as possible. Extension was undertaken first in both muscular action modes.

Each subject performed 5 continuous maximal repetitions. Each set assessed reciprocal muscular action in the dominant leg. The order of testing started with concentric actions, followed by a 120 -second rest before the performance of the eccentric actions. Visual feedback of moment versus time was provided during the test, but no verbal feedback was given (18). The maximal knee flexion and extension peak moment of force of the best repetition in both concentric and eccentric muscular actions were retained and expressed in $\mathrm{Nm}$.

Analysis. Descriptive statistics for chronological age, duration of formal training, estimated APHV, body size, and replicate isokinetic measures were computed for the total sample. Differences between test sessions were examined using the paired $t$ test. Coefficients of variation and ICC were calculated (5). Variability in isokinetic dynamic muscle performance between sessions was expressed as the 95\% confidence interval (CI). Heteroscedasticity was checked using plots of the log-transformed data. Reliabilities (absolute and percent typical errors) were calculated $(5,19)$. The effect size correlations (ES-r) were estimated using the square root of the ratio of $t$ value squared and the difference between $t$ value squared and degrees of freedom (total amount of variance in the sample) (20).

Relationships of variation in means of the differences between the maximal moment of force in concentric and eccentric muscle actions in the first and second test sessions with chronological age, estimated APHV, duration of formal training, stature, body weight, leg length, leg volume, and initial isokinetic strength (first test session) was examined with Pearson correlations. The magnitude of correlations were interpreted as follows: trivial $(r<0.1)$, weak $(0.1<r<0.3)$, moderate $(0.3<r<0.5)$, strong $(0.5<r<0.7)$, very strong $(0.7<r<0.9)$ and nearly perfect $(r>0.9)$ and perfect $(r=1)(21)$. Positive correlation values indicate an increasing linear relationship and negative correlations indicate a decreasing linear relationship between the variables. Significance was set at $P<0.05$. Statistical analyses were performed using the SPSS version 17.0 software (SPSS, Chicago, IL).

\section{Results}

Characteristics of the sample are presented in Table 1. With the exception of two participants, maturity offset values were positive indicating that the sample was beyond the age at maximum growth rate in height during the adolescent spurt. Table 2 shows the differences between means of the two test sessions, and CVs and ICCs of the isokinetic strength indicators.

The difference (mean of mean differences as a

Table 1. Descriptive Statistics for the Total Sample $(n=27)$

\begin{tabular}{|c|c|c|c|}
\hline Characteristic & Mean & $\begin{array}{l}\text { Standard } \\
\text { deviation }\end{array}$ & Range \\
\hline \multirow{2}{*}{$\begin{array}{l}\text { Chronological age, years } \\
\text { Duration of formal training, } \\
\text { years }\end{array}$} & 15.2 & 0.5 & $14.1 ; 16.0$ \\
\hline & 6.0 & 2.7 & $2.0 ; 11.0$ \\
\hline Maturity offset, years & 1.76 & 0.90 & $-0.11 ; 3.36$ \\
\hline Estimated age at PHV, years & 13.50 & 0.87 & $11.97 ; 15.13$ \\
\hline Stature, $\mathrm{cm}$ & 176.9 & 11.9 & $155.1 ; 197.2$ \\
\hline Body weight, $\mathrm{kg}$ & 68.1 & 11.7 & $44.9 ; 87.3$ \\
\hline Sitting height, $\mathrm{cm}$ & 92.1 & 6.0 & $80.1 ; 103.2$ \\
\hline Leg length, cm & 84.0 & 7.3 & $61.8 ; 97.4$ \\
\hline Leg volume, $\mathrm{L}$ & 8.84 & 1.78 & $5.56 ; 11.78$ \\
\hline
\end{tabular}


Table 2. Reliability Estimates of Concentric and Eccentric Knee Flexion and Extension Peak Torque at $60^{\circ} \mathrm{s}^{-1}$ Measured in Two Sessions in Adolescent Basketball Players $(n=27)$

\begin{tabular}{|c|c|c|c|c|c|}
\hline Parameter & $\begin{array}{l}\text { Session } 1 \\
\text { Mean (SD) }\end{array}$ & $\begin{array}{l}\text { Session } 2 \\
\text { Mean (SD) }\end{array}$ & $\begin{array}{c}\text { Mean Difference } \\
(95 \% \mathrm{CI})\end{array}$ & $\begin{array}{c}\mathrm{CV}, \% \\
(95 \% \mathrm{CI}) \\
\end{array}$ & $\begin{array}{c}\mathrm{ICC} \\
(95 \% \mathrm{CI}) \\
\end{array}$ \\
\hline Knee ext & $172.4(36.9)$ & $180.0(37.2)$ & $7.6(0.2 ; 14.9)$ & $8.1(6.3 ; 11.2)$ & $0.89(0.77 ; 0.95)$ \\
\hline Knee flex ecc, Nm & $220.0(69.2)$ & $230.2(70.2)$ & $10.0(-5.9 ; 25.9)$ & $16.5(12.8 ; 23.0)$ & $0.78(0.58 ; 0.90)$ \\
\hline Knee flex con, Nm & $95.5(21.7)$ & $102.5(24.1)$ & $7.2(1.0 ; 13.4)$ & $15.1(11.7 ; 21.2)$ & $0.74(0.51 ; 0.87)$ \\
\hline Knee ext ecc, Nm & $157.7(41.0)$ & $157.4(49.0)$ & $-0.3(-13.1 ; 11.9)$ & $17.4(13.4 ; 24.5)$ & $0.72(0.47 ; 0.86)$ \\
\hline
\end{tabular}

Ext, extension; flex, flexion; con, concentric; ecc, eccentric; CV, coefficient of variance; ICC, intraclass coefficient.

percentage) between test sessions of concentric muscular actions was $4.6 \%(95 \% \mathrm{CI}, 0.2$ to $9.2 ; P<0.05$; $\mathrm{ES}-r=0.38)$ and $8.4 \%(95 \% \mathrm{CI}, 0.2$ to $17.3 ; P<0.05$; $\mathrm{ES}-r=0.42$ ) for knee extension and flexion, respectively. For eccentric muscular actions, differences between sessions were 5.1\% (95\% CI, -3.5 to 14.5 ; $P>0.05$; ES $-r=0.26)$ and $-1.9 \%(95 \% \mathrm{CI},-10.3$ to 7.3; $P>0.05$; ES $-r=0.01)$ for knee flexion and extension, respectively.

Values of the mean peak moment of force for the second test session were higher than for the first session in all muscular actions with an exception of eccentric knee extension (Table 2). Effect sizes of within-subject variation were only moderate. The CV for concentric knee extension was 8.1\% (95\% CI, 6.3 to 11.2 ), while CVs for other muscular actions ranged from $15.1 \%$ to $17.4 \%$. The retest correlations ranged from 0.72 to 0.89 .

The pairwise CVs between test sessions 2 and 3 for the subsample of 8 athletes were $4.9 \%$ and $6.0 \%$ for concentric knee extension and flexion, respectively, and $3.9 \%$ and $5.3 \%$ for eccentric knee flexion and extension, respectively (Table 3 ). The corresponding ICCs ranged from 0.95 to 0.99 .

Correlations between the variance in withinsubject variation between the two test sessions and age, estimated APHV, duration of formal training, body size, lower-body morphology (length and volume), and initial strength are presented in Table 4. Variance in within-subject variation for concentric
Table 3. Reliability Estimates in the Subsample of Adolescent Basketball Players ( $\mathrm{n}=8$ ) Tested on a Third Occasion

\begin{tabular}{lcc}
\hline Parameter & $\begin{array}{c}\text { CV Between } \\
\text { Sessions 2 and 3, \% } \\
(95 \% \text { CI })\end{array}$ & $\begin{array}{c}\text { ICC Between } \\
\text { Sessions 2 and 3 } \\
(95 \% \text { CI })\end{array}$ \\
\hline Knee ext con & $4.9(3.2 ; 10.2)$ & $0.95(0.76 ; 0.99)$ \\
Knee flex ecc & $3.9(2.5 ; 8.8)$ & $0.99(0.92 ; 1.00)$ \\
Knee flex con & $6.0(4.0 ; 12.2)$ & $0.95(0.76 ; 0.99)$ \\
Knee ext ecc & $5.3(3.5 ; 11.1)$ & $0.97(0.87 ; 0.99)$ \\
\hline
\end{tabular}

Ext, extension; flex, flexion; con, concentric; ecc, eccentric; $\mathrm{CV}$, coefficient of variance; ICC, intraclass coefficient.

knee extension was not associated with age, duration of formal training, body size, lower-body morphology, and initial strength. The mean differences between pairwise eccentric knee flexion knee were negatively correlated $(P<0.05)$ with session 1 values of eccentric knee flexion and knee extension. Within-subject differences in the mean differences between pairwise concentric knee flexion were correlated with training experience $(P<0.05)$ and initial values of concentric knee flexion $(P<0.01)$. Withinsubject eccentric knee extension variation was significantly $(P<0.05)$ correlated with chronological age, estimated APHV, stature, body weight, and leg volume, but the correlations were only moderate.

\section{Discussion}

Since statistical analyses revealed differences in reciprocal concentric and eccentric isokinetic assessments at $60^{\circ} \mathrm{s}^{-1}$ between two trials, overall variabil-

Table 4. Correlations Between Variance in Within-Subject Variation Between Two Trials of Isokinetic Muscular Actions at $60^{\circ} \mathrm{s}^{-1}$ With Age, Maturity Status, Years of Formal Training, Body Size, Lower-limb Morphology, and Initial Strength in Adolescent Basketball Players

\begin{tabular}{|c|c|c|c|c|}
\hline Parameter & $\begin{array}{c}\text { Mean Differences } \\
\text { Between Pairwise Knee } \\
\text { Ext Con }\end{array}$ & $\begin{array}{c}\text { Mean Differences } \\
\text { Between Pairwise Knee } \\
\text { Flex Ecc }\end{array}$ & $\begin{array}{c}\text { Mean Differences } \\
\text { Between Pairwise Knee } \\
\text { Flex Con }\end{array}$ & $\begin{array}{c}\text { Mean Differences } \\
\text { Between Pairwise Knee } \\
\text { Ext Ecc }\end{array}$ \\
\hline Chronological age & 0.25 & 0.29 & 0.18 & $0.41^{*}$ \\
\hline Age at PHV & -0.14 & -0.09 & -0.06 & $-0.38^{*}$ \\
\hline Years of formal training & -0.33 & -0.37 & $-0.37 *$ & -0.36 \\
\hline Stature & 0.10 & 0.10 & -0.01 & $0.41^{*}$ \\
\hline Body weight & 0.19 & 0.22 & 0.04 & $0.47^{*}$ \\
\hline Leg length & 0.07 & 0.05 & -0.04 & 0.28 \\
\hline Leg volume & 0.15 & 0.20 & 0.11 & $0.39 *$ \\
\hline Trial 1 knee ext con & -0.33 & 0.02 & -0.28 & 0.11 \\
\hline Trial 1 knee flex ecc & -0.02 & $-0.43^{*}$ & -0.28 & 0.08 \\
\hline Trial 1 knee flex con & -0.11 & -0.24 & $-0.62^{* *}$ & 0.10 \\
\hline Trial 1 knee ext ecc & -0.08 & $-0.42^{*}$ & -0.35 & -0.09 \\
\hline
\end{tabular}

$* * P<0.01 ;{ }^{*} P \leqslant 0.05$. Ext, extension; flex, flexion; con, concentric; ecc, eccentric; PHV, peak height velocity. 
ity in performance cannot be assumed to represent systematic bias (e.g., general learning effect) and random error (biological or mechanical variation) in adolescent basketball players. One familiarization session appeared to be sufficient to measure reliable data under the specified test conditions. Reliability values of replicate measurements after the familiarization session were consistent with CVs $(<6.1 \%)$ and ICCs $(\geqslant 0.88)$ reported in the literature $(2,4)$.

Studies of the reproducibility of the isokinetic peak moments of force measurements are limited, specifically for eccentric actions. Retest correlations for the concentric peak moment of force of knee extensors and flexors in boys aged 6-8 years tested in 3 sessions with 3 -day rest between sessions, using a velocity of $100^{\circ} \mathrm{s}^{-1}$, ranged from 0.85 to 0.95 (9). Among pubertal (pubic hair, stage 3) soccer players aged 13 years, ICCs for the concentric and eccentric knee extensors and flexors of the dominant leg ranged from 0.85 (eccentric) to 0.98 (concentric) (10). The coefficients of variation of $4 \%$ and $9.9 \%$ for the eccentric peak moment of force were documented in 11-year-old boys (22). It was suggested that reliability could have been improved by a familiarization session. Test-retest correlations in the present study after familiarization were consistent with the range of values reported for concentric actions but higher than ICCs reported for eccentric muscular actions. Nevertheless, the reliability estimates from the familiarization session to the second test were lower than values reported in children, and exceeded the limit of values proposed for good reliability in isokinetic strength assessment $(2,4)$.

Few studies have analyzed possible learning effects during day-to-day testing of isokinetic strength. No differences in the concentric peak moment of force in the knee extensors and flexors at $60^{\circ} \mathrm{s}^{-1}$ were noted in adult men and women (3), but comparable data for eccentric knee muscular actions in general and specifically for younger subjects or athletes are lacking. Differences between the first and second test sessions and the reliability estimates for the familiarization session $(n=8)$ suggested the presence of systematic bias and/or random error in both concentric and eccentric muscular actions when testing inexperienced young athletes. The reproducibility in isokinetic strength might be related to biological variation.

Several factors affecting reliability have been noted in the literature $(4,23)$. At the speed used in the present study, isokinetic dynamometry is a valid and reliable testing tool (24). All measurements were made by a single experienced observer. Reliability estimates of the observer for the used protocol, based on repeated measurements in 13 subjects (university

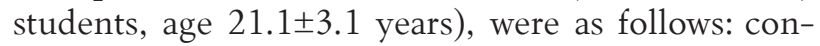
centric knee extension, $\mathrm{CV}=4.1 \%$ and $\mathrm{ICC}=0.98$; concentric knee flexion, $\mathrm{CV}=4.1 \%$ and $\mathrm{ICC}=0.98$; eccentric knee extension, $\mathrm{CV}=5.2 \%$ and $\mathrm{ICC}=0.97$; and eccentric knee flexion, $\mathrm{CV}=4.8 \%$ and $\mathrm{ICC}=0.97$. In order to control potential effects of time-of-day, replicate data were obtained at the same time of day within \pm 30 minutes (25). Therefore, it is possible to assume that within-subject variation in the adopted protocol of isokinetic strength assessment is mainly related to subject-specific factors.

Factors related to subjects, particularly specific issues in pediatric populations, and assessment conditions that may influence dynamometric measurements of extremity muscles have been addressed in the literature $(2,8,26)$. Potential factors include variation in chronological age per se, body size (stature and body weight), limb dominance, presence of impairment, and athletic background; variation in biological maturity status is an additional consideration. Body size, in particular body weight, apparently influences the magnitude of isokinetic moment of force production in adolescent populations (22). Muscle mass has also been indicated as a relevant covariate in the interpretation of isokinetic strength in youth (27), but intrasubject variation does not appear to be related to this measure. It is possible that individual differences in maturity status may influence strength through its effect on body size and muscle mass. Within a given age group of adolescent boys, those advanced in maturation are, on average, taller and heavier and have a larger muscle mass than boys later in maturation (7). To our knowledge, no study has apparently addressed the possible influences of chronological age per se, late adolescent growth in muscle mass (peak rate of growth in muscle mass occurs on average after peak height velocity) and accumulated effects of training on reliability estimates in isokinetic dynamometry.

Age, estimated maturity status, training experience, and body size were the variables correlating with mean within-subject variation between two sessions of isokinetic strength of the hamstrings muscles assessed at $60^{\circ} \mathrm{s}^{-1}$ (concentric knee flexion and eccentric knee extension) and in particular for eccentric contractions (Table 4). The results highlight the importance of age, maturation, and body size in the consideration of the reliability of assessments of knee flexion muscles in adolescent basketball players. As for the assessment of quadriceps muscles (concentric knee extension and eccentric knee flexion), within-subject variation in the concentric action was smaller than in the other muscular actions and closer to reported values in literature. Moreover, within-subject variation in eccentric actions was negatively related to performance values in the familiarization session in both eccentric knee actions. Therefore, higher reliability estimates between the familiarization session and second test 
may be related to higher values of strength in this muscle group.

The issue of maturity-associated variation in isokinetic strength performance has not received much attention (8). Some evidence indicated an increase in concentric knee extension and flexion with age in male and female adolescent athletes but without statistically controlling for interindividual variability in growth and maturation in the analysis (28-30). This is relevant because short-term power outputs improve with age during adolescence independently of pubertal status (7). It is likely that maturity exerts an influence on isokinetic strength performance via body size and muscle mass. Some limited data for male adolescent soccer players showed an independent maturity effect on isokinetic indicators in the knee joint, albeit the limitations of the use of selfreported sexual maturation (31). Overall, the one interested in assessing lower-body isokinetic strength should consider biological inter-individual variation and fitness level as factors that significantly affect measurement reliability. On the other hand, learning effects, i.e., systematic bias, seem to diminish after familiarization session, allowing for more reliable data in adolescent basketball players.

\section{Conclusions}

A familiarization session may improve the reliability of assessment when using concentric and eccentric knee isokinetic strength testing at $60^{\circ} \mathrm{s}^{-1}$ and improve the evaluation of the effectiveness of strength training programs or clinical assessments of adolescent basketball players. Intraindividual and interindividual differences in chronological age, maturity status, and accumulated experience are potential factors that should be considered when using knee isokinetic strength testing at $60^{\circ} \mathrm{s}^{-1}$, in particular for the assessment of the hamstrings muscular actions.

\section{Acknowledgments}

The authors thank for the useful feedback and suggestions on a draft version provided by Carlos Eduardo Gonçalves and António J. Figueiredo. This research was partially supported by Fundação para a Ciência e a Tecnologia [SFRH/BD/41647/2007, PTDC/DES/121772/2010]. The third author was supported by a fellowship from CNPq.

\section{Statement of Conflict of Interest}

The authors state no conflict of interest.

\title{
Paauglių krepšininkų izokinetinio testavimo patikimumo įvertinimas
}

\author{
Humberto M. Carvalho', Manuel J. Coelho E Silva ${ }^{1}$, Enio Ricardo Vaz Ronque ${ }^{2}$, \\ Rui S. Gonçalves ${ }^{3}$, Renaat M. Philippaerts ${ }^{4}$, Robert M. Malina ${ }^{5,6}$ \\ ${ }^{1}$ Koimbros universiteto Sporto mokslo ir kūno kultūros fakultetas, ${ }^{2}$ Londrinos valstybinio universiteto \\ Kūno kultūros katedra, Brazilija, ${ }^{3}$ Koimbros politechnikos instituto Sveikatos technologijų koledžas, Portugalija, \\ ${ }^{4}$ Gento universiteto Medicinos ir sveikatos mokslu fakulteto Judejimo ir sporto mokslu katedra, Belgija, \\ ${ }^{5}$ Teksaso universiteto Ostine Kineziologijos katedra, Teksasas, Jungtinès Amerikos Valstijos, \\ ${ }^{6}$ Tarletono valstybinio universiteto Sveikatos ir kūno kultūros katedra, Stefenvilis, Teksasas, Jungtinès Amerikos Valstijos
}

Raktažodžiai: brendimas, jèga, jauni sportininkai, antropometrija.

Santrauka. İvadas. Buvo vertinamas jaunimo krepšininkų (nuo 14 iki 16 metų) pakartotinių bandymų izokinetinių koncentrinių ir ekscentrinių raumenų judesių atkūrimas, taip pat ryšys tarp dviejų kiekvieno tiriamojo izokinetinio testavimo bandymų vidurkių atsižvelgiant ị chronologinị amžių (CA), biologinį brendimą (nustatomas amžius esant didžiausiam augimo greičiui), treniravimosi patirtị, kūno apimtis, apatinių kūno dalių morfologiją ir staigiosios jègos įvertį.

Tyrimo metodika. Tiriamųju imtị sudarè 27 krepšininkai, kurie atliko pakartotinius testavimo bandymus, sudarytus iš penkių pakartojimų atliekant koncentrinị ir ekscentrinị kelio ištiesimą ir sulenkimą $60^{\circ} \mathrm{s}^{-1}$. Norint patvirtinti rezultatų patikimumą, atsitiktinai atrinktos subgrupès aštuoni tiriamieji, kurie pakartotinai atliko trečiąji bandymą.

Rezultatai. Variacijos koeficientas (VK) tarp pirmojo ir antrojo bandymų varijavo nuo 8,1 iki 17,4 proc., intraklasès koeficientai (IKK) varijavo nuo 0,72 iki 0,89. Antrojo ir trečiojo bandymų VK varijavo nuo 3,9 iki 6,0 proc., o IKK - nuo 0,95 iki 0,99. Pradinè ekscentrinio kelio lenkimo jèga $(r=-0,43)$ ir ekscentrinio kelio tiesimo jejga $(\mathrm{r}=-0,42)$ koreliavo $(\mathrm{p}<0,05)$ su ekscentriniu kelio ištiesimu atsižvelgiant i vidinę variaciją tarp dviejų bandymų. Taip pat apskaičiuota koreliacija tarp tiriamųjų treniravimosi patirties $(r=-0,37$, $\mathrm{p}<0,05)$, pradinių koncentrinio kelio lenkimo reikšmių $(\mathrm{r}=-0,62, \mathrm{p}<0,01)$ ir koncentrinio kelio lenkimo skirtumų. Apskaičiuotas koreliacijos koeficientas tarp kiekvieno tiriamojo ekscentrinio kelio ištiesimo kaitos $(\mathrm{p}<0,05)$ ir VK $(\mathrm{r}=0,41)$, nustatyto amžiaus esant didžiausiam augimo greičiui $(\mathrm{r}=-0,38)$, kūno apimčių $(\mathrm{r}=0,41$ iki 0,47$)$ ir kojų masès $(r=0,39)$. 
Išvados. Supažindinimas su testavimo eiga gali padidinti paauglių krepšininkų atliekamų koncentrinių ir ekscentrinių kelio izokinetinès jègos, esant $60^{\circ} \mathrm{s}^{-1}$, bandymų patikimumą. Atsižvelgti ị amžių, brandos lygị ir jaunų sportininkų treniravimosi patirtị reikia tada, kai testuojamo kelio izokinetinè jẻga lygi $60^{\circ} \mathrm{s}^{-1}$.

\section{References}

1. Lund H, Sondergaard K, Zachariassen T, Christensen R, Bülow P, Henriksen M, et al. Learning effect of isokinetic measurements in healthy subjects, and reliability and comparability of Biodex and Lido dynamometers. Clin Physiol Funct Imaging 2005;25:75-82.

2. Gleeson NP, Mercer TH. The utility of isokinetic dynamometry in the assessment of human muscle function. Sports Med 1996;21:18-34.

3. Gleeson NP, Mercer TH. Reproducibility of isokinetic leg strength and endurance characteristics of adult men and women. Eur J Appl Physiol Occup Physiol 1992;65:221-228.

4. Hopkins WG, Schabort EJ, Hawley JA. Reliability of power in physical performance tests. Sports Med 2001;31:211234.

5. Hopkins WG. Measures of reliability in sports medicine and science. Sports Med 2000;30:1-15.

6. Beunen G, Malina RM. Growth and biological maturation: relevance to athletic performance. In: Bar-Or O, editor. The child and adolescent athlete. Oxford: Blackwell Science; 1996. Vol. 3-24.

7. Malina RM, Bouchard C, Bar-Or O. Growth, maturation, and physical activity. 2nd ed. Champaign, IL: Human Kinetics; 2004.

8. De Ste Croix M, Deighan M, Armstrong N. Assessment and interpretation of isokinetic muscle strength during growth and maturation. Sports Med 2003;33:727-743.

9. Merlini L, Dell'Accio D, Granata C. Reliability of dynamic strength knee muscle testing in children. J Orthop Sports Phys Ther 1995;22:73-76.

10. Kellis E, Kellis S, Gerodimos V, Manou V. Reliability of isokinetic concentric and eccentric strength in circumpubertal soccer players. Pedia Exerc Sci 1999;11:218-228.

11. Thomas JR, Nelson JK. Research methods in physical activity. Champaign, IL: Human Kinetics; 2001.

12. Wrigley T, Strauss G. Strength assessment by isokinetic dynamometry. In: Gore CJ, editor. Physiological tests for elite athletes. Champaign, IL: Human Kinetics; 2000.

13. Bagger M, Petersen PH, Pedersen PK. Biological variation in variables associated with exercise training. Int J Sports Med 2003;24:433-440.

14. Lohman TG, Roche AF, Martorell R. Anthropometric Standardization Reference Manual. Champaign, IL: Human Kinetics 1988.

15. Jones PR, Pearson J. Anthropometric determination of leg fat and muscle plus bone volumes in young male and female adults. J Physiol 1969;204:63P-66P.

16. Malina RM. Anthropometry. In: Maud PJ, Foster C, editors. Physiological assessment of human fitness. Champaign, IL: Human Kinetics; 1995. p. 205-20.

17. Mirwald RL, Baxter-Jones AD, Bailey DA, Beunen GP.
An assessment of maturity from anthropometric measurements. Med Sci Sports Exerc 2002;34:689-694.

18. Baltzopoulos V, Williams JG, Brodie DA. Sources of error in isokinetic dynamometry: effects of visual feedback on maximum torque. J Orthop Sports Phys Ther 1991;13:138-42.

19. Bland JM, Altman DG. Statistical methods for assessing agreement between two methods of clinical measurement. Lancet 1986;1:307-10.

20. Rosnow RL, Rosenthal R. Computing contrasts, effect sizes, and counternulls on other people's published data: General procedures for research consumers. Psychological Methods 1996;1:331-340.

21. Hopkins WG. A scale of magnitudes for effect statistics. A new view of statistics. 2002. Available from: URL: http:// www.sportsci.org/resource/stats/index.html. [accessed December 10, 2010].

22. Mohtadi NG, Kiefer GN, Tedford K, Watters S. Concentric and eccentric quadriceps torque in pre-adolescent males. Can J Sport Sci 1990;15:240-243.

23. Currell K, Jeukendrup AE. Validity, reliability and sensitivity of measures of sporting performance. Sports Med 2008; 38:297-316.

24. Drouin JM, Valovich-mcLeod TC, Shultz SJ, Gansneder BM, Perrin DH. Reliability and validity of the Biodex system 3 pro isokinetic dynamometer velocity, torque and position measurements. Eur I Appl Physiol 2004;91:22-9.

25. Wyse JP, Mercer TH, Gleeson NP. Time-of-day dependence of isokinetic leg strength and associated interday variability. Br J Sports Med 1994;28:167-70.

26. Keating JL, Matyas TA. The influence of subject and test design on dynamometric measurements of extremity muscles. Phys Ther 1996;76:866-89.

27. Housh TJ, Stout J, Housh DJ, Johnson GO. The covariate influence of muscle mass on isokinetic peak torque in high school wrestlers. Pedia Exerc Sci 1995;7:176-82.

28. Camic CL, Housh TJ, Weir JP, Zuniga JM, Hendrix CR, Mielke $M$, et al. Influences of body-size variables on agerelated increases in isokinetic peak torque in young wrestlers. J Strength Cond Res 2010;24:2358-65.

29. Buchanan PA, Vardaxis VG. Lower-extremity strength profiles and gender-based classification of basketball players ages 9-22 years. J Strength Cond Res 2009;23:406-19.

30. Gerodimos V, Mandou V, Zafeiridis A, Ioakimidis P, Stavropoulos N, Kellis S. Isokinetic peak torque and hamstring/ quadriceps ratios in young basketball players. Effects of age, velocity, and contraction mode. I Sports Med Phys Fitness 2003;43:444-52.

31. Forbes H, Bullers A, Lovell A, McNaughton LR, Polman RC, Siegler JC. Relative torque profiles of elite male youth footballers: effects of age and pubertal development. Int J Sports Med 2009;30:592-7. 